\title{
Moralitas dan Agama dalam Konteks Kehidupan Berbangsa dan Bernegara: Antara Moralitas Privat dan Moralitas Publik
}

\section{Mudjia Rahardjo}

Penulis adalah Dosen tetap pada Fakultas Adab UIIS Malang \& Kandidat Doktor Sosiolinguistik Universitas Airlangga

\section{A Pengantar}

Multikrisis yang melanda Indonesia sejak pertengahan 1997 menurut beberapa ahli sudah berada di luar daya penjelas (explanatory power) berbagai disiplin ilmu; ekonomi, politik, sosial dan sebagainya. Sebab; kendati berbagai upaya recovery (ekonomi maupun sosial politik) telah dilakukan berbagai pihak toh kenyataannya belum membuahkan hasil yang optimal.

Terpilihnya Abdurrahman Wahid sebagai presiden pada 20 Oktober 1999 dianggap menjadi tumpuan harapan bagi penyelesaian sederet persoalan sosial, ekonomi, dan politik warisan pemerintahan sebelumnya (Alhumami, 2000). Namun dalam perjalanannya, pemerintahan ini bukan saja tidak mampu memulihkan kehidupan ekonomi, sebagaimana harapan semula, tetapi justru melahirkan gonjang ganjing politik yang berujung pada jatuhnya pemerintahan ini 23 Juli 2001. Naiklah Megawati Soekamoputri sebagai Presiden menggantikan Abdurrahman Wahid yang tersandung kasus Buloggate dan Bruneigate.

Tetapi pemerintahan baru di bawah Megawati Soekamoputri ini pun juga belum ada tanda-tanda mampu 
menyelesaikan berbagai persoalan bangsa. Publik menyaksikan tumpang tindihnya perjalanan birokrasi kabinet Megawati. Akibatnya, pemulihan ekonomi yang dinantinantikan banyak pihak berjalan sangat lamban, terbukti nilai tukar rupiah yang fluktuatif, investasi asing yang tak kunjung datang, stabilitas sosial politik yang sangat rentan dan praktik kekerasan masih terus terjadi. Ditambah lagi bencana alam berupa banjir dan tanah longsor yang melanda beberapa daerah dan ancaman disintegrasi.

Mencermati kondisi bangsa demikian, banyak orang bertanya apakah bangsa ini tidak mampu menyelesaikan berbagai persoalan tersebut atau memang tidak mau? Tulisan ini akan mencoba menjelaskan dan memahami persoalan bangsa ini dalam perspektif moral dan agama.

\section{B. Antara Moralitas Privat dan Moralitas Publik}

Tidak sedikityang mengatakan bahwa berbagai kesulitan bangsa ini timbul karena moralitas bangsa merosot baik di kalangan elit penguasa maupun anggota masyarakat biasa. Padahal, tidak bisa disangkal bahwa moralitas sangat penting bukan hanya untuk kehidupan pribadi tetapi juga sosial. Moralitas biasanya dikaitkan dengan agama. Moralitas dapat diting-katkan jika kehidupan agama diperbaiki. Pendidikan agama dapat diperbaikijika pendidikan agama berlangsung baik. Tetapi persoalannya adalah sedemikian sederhanakah sumber peresoalan bangsa dan upaya penyelesaiannnya? Atau salahkan pendidikan moralitas yang diajarkan lewat agama?

Kehidupan berbangsa dan bernegara memang mensyaratkan adanya moralitas publik yang kukuh. Nalar sederhananya adalah jika moralitas masyarakat baik, maka penyelenggaraan negara akan tertib dan aman. Tetapi perlu diingat bahwa moralitas publik berbeda dengan moralitas privat. Menurut Kleden (2000: 4), agama-agama secara umum lebih mengajarkan moralitas privat kepada pemeluknya ketimbang moralitas publik. Misalnya, agama tidak secara langsung mengajarkan bagaimana berlalulintas yang baik, bagaimana menjaga ketertiban dan kebersihan kota, bagaimana menjaga lingkungan hidup yang lestari, bagaimana sikap kita jika sedang antri membayar telepon dan listrik, bagaimana berdemonstrasi menyampaikan aspirasi, bagaimana bergaul dan berhubungan dengan warga dan bangsa lain dalam konteks regional dan global dan sebagainya. Semua hal tersebut menyangkut moralitas publik yang sangat penting bagi kehidupan dan penyelenggaraan kenegaraan.

Realitas sering menunjukkan banyak orang yang berlatarbelakang kehidupan agama yang baik sering kali melanggar moralitas publik dan karenanya tidak menjadi warga negara yang baik. Contoh yang paling gamblang adalah persoalan KKN (Korupsi, Kolusi, dan Nepotisme) yang merajalela di negeri ini justru banyak dilakukan oleh orangorang yang berpendidikan tinggi dan dan bahkan berbasis kehidupan agama yang baik. Berbagai slogan juga sering kita dengar 
bahwa di negeri ini tumbuh subur kehidupan beragama.

Ini sama halnya, kendati agamaagama mengajarkan kedamaian (harmoni) dan saling hormat kepada orang lain, toh dalam kenyataannya konflik sosial di masyarakat kita berlangsung seakan tiada henti. Memberi rasa aman dan rasa saling hormat kepada orang lain tampaknya menjadi semakin sulit di negeri ini. Hal ini semakin jelas dalam pendidikan agama di sekolah-sekolah. Di Indonesia hidup berbagai agama yang secara yuridis formal diakui oleh negara. Konsekwensi logisnya semua agama itu memiliki hak hidup dan perlu dihormati oleh setiap warga negara.

Tetapi kenyataannya pendidikan agama kurang mengajarkan heterogenitas agama ini. Pendidikan agama hanya mengajarkan persoalan-persoalan privat ajarannya seperti bagaimana salat dan bagaimana membaca kitab suci yang baik dan benar, bagaimana berzakat dan sebagainya. Malah ada yang mengajarkan fanatisme keagamaan secara sempit sehingga anak didik justru semakin tidak hormat kepada agama lain. Pendidikan demikian jelas akan melahirkan moralitas privat ketimbang moralitas publik yang mestinya merupakan a sufficient condition bukan sekadar a prerequisite condition bagi berlangsungnya kehidupan berbangsa dan bernegara yang sangat heterogen ini.

Model pendidikan agama tersebut perlu memperoleh penegasan agar kita, meminjam istilah Kleden (2000) tidak terjebak ke dalam moralist fallacy yang mengelirukan, bahwa jika negara dikelola oleh orang-orang yang secara cultural berbasis kehidupan religius yang baik dan memiliki moralitas privat yang yang tinggi, maka dengan sendirinya pelaksanaan pemerintahan akan berjalan baik sehingga rakyat akan makmur dan sejahtera. Tetapi bagaimana kenyataannya kehidupan di negara kita sekarang ini? Kurangkah orangorang pemerintahan yang berbasis agama dan berpendidikan yang cukup tinggi? Toh kenyataannya korupsi yang menjadi biang kerok ambruknya kehidupan ekonomi di Indonesia merajalela sehingga Indonesia menjadi salah satu negara terkorup di dunia setelah Brasil. Untuk diketahui jumlah tunggakan debitor nakal yang sampai hari ini belum mampu dibayar mencapai lebih dari 136 trilyun rupiah. Selain itu, korupsi, kekerasan, teror, dan pelanggaran HAM terus saja terjadi saat ini.

Gambaran di atas sama sekali tidak berarti pendidikan moral dan agama tidakada gunanya bagi kehidupan berbangsa dan bernegara. Sebab, orang yang beragama paling tidak mampu menahan diri dari nafsunafsu pribadinya sehingga tidak banyak merepotkan dalam kehidupan publik. Namun demikian, moralitas privat itu belum cukup. Hal ini karena moralitas privat tidak sama dengan moralitas publik, sekalipun keduanya tidak bertentangan.

Kehidupan dalam komunitas agama dan kehidupan sebagai warga negara merupakan hal yang berbeda. Dalam kehidupan komunitas agama, setiap agama mempunyai hak penuh untuk berbeda dari agama lain. Dengan kata lain, setiap agama benar bagi pemeluknya. Secara sosiologis, 
agama merupakan bagian kehidupan budaya, dan setiap budaya mempunyai hak untuk hidup bahkan berkembang sesuai nilainilai budaya mereka. Dan, negara tidak mempunyai hak mengintervensi nilai-nilai tersebut, sepanjang nilai-nilai tersebut tidak bertentangan dengan hukum negara. Sebaliknya dalam kehidupan negara, semua warga negara memiliki hak dan kewajiban sama.

Selain setiap agama memiliki nilai-nilai kebenaran masing-masing yang dipercayai pemeluknya, antara agama yang satu dan yang lain tidak mungkin dilakukan kompromi nilai-nilai dan ajarannya yang bisa diperlakukan bagi pemeluk agama lain. Agama merupakan urusan privat bagi pemeluknya yang tidak bisa diintervensi oleh nilai-nilai agama lain. Sebaliknya, dalam negara yang penyelenggaraannya diatur lewat politik sering kali melalui kompromi antara kelompok yang satu dengan yang lain demi kepentingan publik. Dengan demikian, dalam penyelenggaraan negara politik merupakan hal yang negotiable. Tidak ada yang tidak mungkin dalam politik.

\section{Penutup}

Menerjemahkan moralitas privat menjadi moralitas publik tentu bukan persoalan mudah. Siapa yang bisa menyangkal bahwa bangsa Indonesia selama ini dikenal sebagai bangsa yang halus, sopan dan santun serta ramah dan agamis. Berbagai atribut baik seakan melekat pada diri bangsa ini. Tiba-tiba bangsa ini berubah menjadi bangsa yang kasar dan pemarah serta menakutkan. Bahkan menurut Beny Susetyo, bangsa ini sudah kehilangan jati dirinya (Kompas, 22/2/02).

Kesopanan dan kesantunan yang melekat pada diri bangsa ini ternyata hanya berlaku pada rung privat. Adakah dalam sejarah perjalanan bangsa ini adakah pejabat negara yang berani mengakui "salah" dalam melaksanakan tugasnya kemudian menyatakan permintaan maaf kepada rakyat? Adakah politisi kita yang masih jernih berpikimya dan berpihak pada kepentingan rakyat, selain Sophan Sofian dan Dimyati Hartono yang kemudian hengkang dari lembaga legislatif?

Tampaknya, saat ini kita semua bisa menyaksikan para pemimpin, politisi, elit politiknegeri ini menjelmakan ketidakjujuran dalam aneka rupa. Ketidakjujuran menjelma dalam kebohongan, yaitu pengucapan ketidakbenaran di hadapan publik dengan mengkambinghitamkan orang lain. Misalnya, dugaan mega korupsi Akbar Tandung yang saat ini sedang memperoleh perhatian publik secara luas. Kita bisa menyaksikan dagelan para politisi kita di Gedung Wakil Rakyat atas masalah tersebut. Mengapa dulu mereka begitu getol menyelidiki Presiden Abdurrahman Wahid dalam kasus yang kurang lebih sama ini.

Ketidakjujuran juga menjelma dalam pelaksanaan profesi, tugas, atau pekerjaan yang penuh kepura-puraan dan merebakkan ketidakadilan seperti dilakukan sebagian hakim, pengacara, jaksa, dan polisi yang menabiri ketidakbenaran dengan pasal-pasal undang-undang. Ketidakjujuran juga menjelma dalam kesaksian palsu, upaya 
menghalangi perwujudan kebenaran, dan pengalihan perhatian masyarakat luas atas masalah yang menimpa penguasa dan elit negeri ini.

Sikap pengecut dan licik juga dipertontonkan oleh para jenderal yang diduga terlibat dalam berbagai aksi pelanggaran HAM dan secara terangterangan menolak panggilan KPP HAM yang akan mengusut kasus tragedi Trisakti, Semanggi I, Semanggi II, kekerasan di Ambon, Sampit, dan Papua atas terbunuhnya tokoh Papua Theys. Secara terang-terangan, ruang publik telah dilecehkan oleh para politisi dan penggede negeri ini yang sering kali berbicara pentingnya tegaknya hukum.

Lemahnya moralitas publik para pemimpin, politisi dan elit negeri ini yang ditunjukkan lewat ketidakjujuran, kebohongan, kelicikan, kemunafikan, penipuan, ketidakadilan, kerakusan, kesombongan dan sebagainya benar-benar menggiring perjalan bangsa ini ke jalan yang sangat rumit sehingga bangsa ini menjadi lelah. Jangankan bersaing dengan bangsa lain, untuk hidup sendiri saja secara wajar tampaknya masih sulit.

Berbagai kemelut kehidupan berbangsa dan bernegara tersebut tidak akan pernah selesai jika para pemimpin, elit politik, dan politisi negeri ini tidak lebih dulu mentransformasikan moralitas privat mereka ke dalam moralitas publik secara komprehensif. Sebab, kenyataannya kesantunan, keramahan, dan kesalehan masyarakat kita hanya hidup dalam ruang privat. Tampaknya, ruang publik belum merupakan "istilah" yang akrab di telinga masyarakat kita, termasuk para pemimpin, politisi, dan elit negeri ini.

Dengan demikian, memahami agama secara privat di kalangan para pemimpin sama sekali belum menjadi jaminan terselenggaranya kehidupan berbangsa dan bermegara secara baik. Sebab, beragama dalam. ruang privat baru merupakan $a$ necessary condition (syarat yang diperlukan) belum merupakan $a$ sufficient condition (syarat yang cukup) bagi tatanan kehidupan secara ideal. 